\title{
Utilization of mine water of Kryvbas as an imperative for sustainable development of Dnipropetrovsk region
}

\author{
Oleksandr Amosha, Hanna Shevtsova*, and Ziya Memedlyaev \\ Institute of Industrial Economics of the NAS of Ukraine, 2 M. Kapnist Str., Kyiv, 03057, Ukraine
}

\begin{abstract}
Sustainable development is a wide area of scientific discourse based on the interdisciplinary approach that integrates research in the natural, technical and social sciences. It is a multidimensional concept that reveals complex interactions between society, economy and environment. This work highlights problems of sustainable development of old industrial regions with the dominance of the mining industry. The latter creates a high human burden on the environment and leads to ecological and social problems. One of the most important tasks of ensuring the long-term environmental sustainability of the Dnipropetrovsk region in Ukraine is utilization of highly mineralized mine water of Kryvbas. From the standpoint of sustainable development, mine water should be considered as a hydro-mineral resource of many valuable components including bromine. In this work we justify the creation of bromine production from mine water of Kryvbas. Potential profitability of the production is largely based on innovative technical and technological solutions. We examine the market and many aspects of the pilot project, including its technological, investment and economic specifics. We highlight the relevance of this project and suggest a possibility for its implementation within the regional strategy framework.
\end{abstract}

\section{Introduction}

Sustainable development is a comprehensive interdisciplinary concept that covers different levels and areas of human life. It aims to bridge the gap between natural, technical and social sciences and to focus collective efforts on difficult challenges.

It is a multidimensional concept that investigates complex interactions between society, economy and environment. That is why most studies, particularly [13], examine three dimensions of sustainable development:

1) social solidarity (inclusive growth with equal opportunity for all people, poverty eradication, improving the well-being, gender equality, safety, social cohesion);

2) economic efficiency (economic growth, increased trade, employment, optimal use of limited resources, technological development, innovations, increased investment and productivity);

3) environmental responsibility (safeguarding the environment, keeping the equilibrium and integrity of ecosystems, waste management, control of climate change, biodiversity conservation).

The balanced development of these components is also important. N. Derlukiewicz [1] emphasizes that according to the sustainable development concept, future needs can be met depending on how well social, economic, and environmental objectives or needs are balanced.
S. Talukdar [4] conceptualizes sustainability in terms of environmental, physical, social and economic dimensions of sustainability. He also identifies two sustainability goals: continuity and aspiration.

D. Hanss \& G. Bohm [5] discuss such dimensions of sustainability as environmental, social, developmental, temporal, and economic. According to the authors, development, new technologies, research and unsolved problems belong to developmental dimension of sustainability. We agree with this classification and use its elements in our case study. We think that this developmental dimension may also be called "innovative".

E. Holden et al. [6] examines four primary dimensions: safeguarding long-term ecological sustainability, satisfying basic human needs, and promoting intragenerational and intergenerational equity. The authors also underline the distinction between narrow and broad sustainability. The narrow sustainability places great emphasis on long-term ecological sustainability. The broad sustainability also includes a wide range of political, social, economic and cultural issues.

Sustainable development is not only a scientific concept, but a political vision too. There are many regional, national, and global sustainability studies that have been successfully used in policymaking.

But eventually, we agree with I. Ilic-Krstic et al. [2] that the general concept of sustainability can have different forms depending on the framework being used. In the context of this study, the attributes of sustainable 
development are important for solving regional- and project-level problems.

The sustainable development approach is of particular significance to address the challenges in old industrial regions. Basic industries are dominant in these regions, because they were mostly formed and developed long ago.

Old industries are primarily based on extensive use of local raw materials, have outdated technologies, low productivity and accumulated environmental problems. Therefore, structural modernization is one of the key challenges in transformation of old industrial regions.

A number of researchers investigate problems of old industrial regions and a possibility of their neo-industrial modernization, see [7-11].

K. Birch et al. [7] studies diverse experiences among old European industrial regions and the role of national varieties of capitalism in shaping regional trajectories and the different mechanisms of regional adaptation. L. Coenen et al. [8] analyzes the potential, barriers and limitations for regional innovation policy to facilitate industrial renewal in old industrial regions.

The authors of [10] analyze how to ensure future sustainable development of old industrial coal-mining regions. The authors emphasize that there is no need for drastic changes, such as radical transformation in technologies, business organization patterns, or composition and quality of used resources (including labor). Instead, one may start with using technologies and business models that have a possibility to diversify the current economic activity. This possibility comes from similarity in the knowledge base and workers' qualification between different industries that are not connected both in the value chain and in the goodsdependent trade. An example of such diversification for the old coal-mining regions is a circular production that returns coal mining and enrichment waste back into production cycle by using innovative technologies.

Continuing research in this direction, we substantiate one of the possible project-level solutions as part of ensuring the long-term sustainability of the Dnipropetrovsk region in Ukraine.

\section{The problem of Kryvbas mine water utilization}

Dnipropetrovsk region is one of the most industrialized regions of Ukraine. According to State Statistics Service of Ukraine, it makes one fifth of Ukrainian industrial product sales.

The mining industry $(27.2 \%$ of total sales in 2018) and metallurgical production $(37.7 \%$ of sales) are the key industrial sectors of the region; they form basis of a powerful mining and smelting complex.

However, these industries are medium-low-tech. This leads to unsound technological structure, which is worse than the structure of other industrial regions. The structural and technological modernization of the region is blocked for institutional, political, functional and other reasons. At the same time, these sectors create a high human burden on the environment and worsen the ecological and social situation in the region.

Kryvbas (Kryvyi Rih Iron Ore Basin) is the largest ore mining region in Ukraine. Mining operations form a significant amount of mineralized water that is usually discharged into natural water sources. There are different options to drain, process and use mine and quarry waters of Kryvbas, but all of them have shown to be flawed [12].

As indicated in the current Strategy for development of the region until 2020: "Dnipropetrovsk region is one of the worst in terms of access to qualitative drinking water. Most of its cities entered a pre-crisis or crisis hydrological and ecological situation because selfrecovery of the Dnieper and many rivers of the basin can no longer restore the upset ecological balance. The quality of surface water does not meet requirements of economic and household consumption. One of the main problems of the region is the pollution caused by mine water" [13].

As stated by a number of regional environmental programs (e.g. the Dnipropetrovsk regional comprehensive strategy of environmental safety and prevention of climate change for 2016-2025, and the long-term program to solve the environmental problems of Kryvbas for 2011-2022) protection and sustainable use of water resources, as well as purification and processing of highly mineralized mine water are the two priority directions for development of the region.

One of the most important aspects of mine water processing is the extraction of valuable components. According to experts [14], up to 20 million $\mathrm{m}^{3}$ of highly mineralized mine water is pumped out in Kryvbas every year. Notably, this water contains bromine in such concentration that allows us to consider its industrial production.

In this work we justify the creation of bromine production from mine water of Kryvbas.

\section{Extraction of bromine from mine water of Kryvbas}

\subsection{Market aspect}

Until recently, the domestic needs of Ukraine for bromine and its derivatives were fully provided by the industrial production of bromine from the Lake Sivash brine in PJSC Brom, Crimea. According to Statista [15], Ukraine produced around 3500 metric tons of bromine in 2013. According to State Statistics Service of Ukraine, the annual revenues from bromine export were around $\$ 1 \mathrm{mln}$.

However, due to the annexation of Crimea Ukraine lost its bromine production and is forced to purchase imported bromine-containing products. The resulting changes in the supply/demand balance of bromine in the domestic market actualize the idea of extracting bromine from the mine water of Kryvbas.

According to [16], about 820000 tons of bromine are produced globally every year. Over the past 15 years the market price of bromine has increased 7 times. The 
leading countries producing bromine and its compounds are USA, Israel, Jordan, China and Japan. They account for $98 \%$ of world production, see Table 1 compiled according to the data of $[15,17]$.

Table 1. Major countries in worldwide bromine production.

\begin{tabular}{|c|c|c|}
\hline Country & $\begin{array}{c}\text { Bromine pro- } \\
\text { duction in 2018, } \\
\text { ths tons }\end{array}$ & $\begin{array}{c}\text { Bromine } \\
\text { concentration by } \\
\text { source, } \mathbf{g} / \mathbf{l}\end{array}$ \\
\hline USA & $-^{*}$ & $\begin{array}{c}\text { Brine wells }-2-6 \\
\text { Dead Sea brine }-10-12\end{array}$ \\
\hline Israel & 190 & Dead Sea brine $-10-12$ \\
\hline Jordan & 100 & Dead Sea brine $-10-12$ \\
\hline China & 60 & $\begin{array}{c}\text { Underground wells }- \\
0.2-0.3 \\
\text { Sea water }-0.05\end{array}$ \\
\hline Japan & 20 & Sea water -0.05 \\
\hline $\begin{array}{c}\text { Ukraine (temporari- } \\
\text { ly occupied territo- } \\
\text { ry) }\end{array}$ & 4.9 & Shallow sea $-0.6-1$ \\
\hline India & 1.7 & Lake $-3-4$ \\
\hline
\end{tabular}

*Figures for the U.S. have withheld to avoid disclosing company proprietary data.

The demand for bromine is growing (by 1-2\% per year on average) because of its widespread use. Nowadays, a lot of bromine is used in production of flame retardants, which protect organic materials from ignition. A significant amount of bromine is also consumed in production of drilling fluids that are used for drilling oil and gas wells. Another area of bromine use is production of pesticides and insecticides for agriculture. Elemental bromine and its compounds are also used in water cleaning and treatment. Bromine is sometimes used for mild disinfection of pool water instead of chlorine. Other application areas of bromine compounds are pharmaceuticals and cosmetics, photographic chemicals, desiccants for cooling systems, dyestuffs, lead scavenger in anti-knock fuels, monomers for specialty polymers, bleaching and oxidizing chemicals, precision cleaning [17-19].

\subsection{Technological aspect}

The choice of bromine extraction technology mostly depends on concentration of bromide-ion in water. For instance, steam desorption is used to extract bromine from the Dead Sea brine, while air-desorption is used in extraction at Lake Sivash.

The concentration of bromide-ion in the mine water of Kryvbas requires the air-desorption extraction method. In this case, the main limiting stage of production is a desorption process that occurs in a countercurrent packed apparatus (desorber). For example, a titanium desorber loaded with a plastic screw packing is nowadays used in the industrial practice [20].

The high cost of titanium significantly affects the capital costs. This actualizes the search for ways to drastically reduce the size and metal/material consumption of technological equipment and, first of all, the desorber as the largest unit.
As part of a pilot project that recycles $500 \mathrm{~m}^{3}$ of mine water per hour in Kryvbas, we propose an innovative solution that greatly reduces the capital costs, see Table 2.

Table 2. Comparative analysis of the technical characteristics of traditional and innovative core equipment.

\begin{tabular}{|c|c|c|}
\hline \multirow{2}{*}{ Indicators } & \multicolumn{2}{|c|}{ Desorber } \\
\cline { 2 - 3 } & Traditional & Innovative \\
\hline Material & Titanium & Titanium \\
\hline Diameter, $\mathrm{m}$ & 4.6 & 2.0 \\
\hline Packed bed & Screw-type & Screw-type \\
\hline Height of packed layer, $\mathrm{m}$ & 12 & 4 \\
\hline Irrigation intensity, $\mathrm{m}^{3} / \mathrm{m}^{2} \cdot \mathrm{h}$ & 30 & 150 \\
\hline Air velocity, $\mathrm{m} / \mathrm{s}$ & 1.4 & 5.7 \\
\hline Hydrodynamic regime & Film & Flooding \\
\hline Extraction rate, $\%$ & 88 & 88 \\
\hline Packed bed volume, $\mathrm{m}^{3}$ & 199.3 & 12.6 \\
\hline Titanium consumption, tons & 20.8 & 4.5 \\
\hline
\end{tabular}

The project is based on the air-desorption method and using a critical hydrodynamic flooding regime. The latter provides an extremely high productivity and efficiency but is very unstable and may cause a technological disaster by flooding countercurrent packed apparatuses with gas/liquid emulsion. Therefore, this regime is generally considered a strict taboo.

Our innovative idea is to make the flooding regime work without disasters by making it stable both under constant and variable loads with the help of its hydraulic self-organization. The implementation of this idea was made possible due to the synergistically oriented architecture of the desorber, which has demonstrated promising results during pilot tests.

The scientific novelty consists in the new flow organization, which depending on the relative position of the desorber and fan looks as shown in Figure 1, where $L$ - liquid flow (mine water), $G_{1}$ and $G_{2}$ - main and additional air flows, and quantitatively, $G_{2}$ is at least 3$5 \%$ of $G=G_{1}+G_{2}$.

Such flow organization provides hydraulic selforganization of the flooding regime and makes it working.
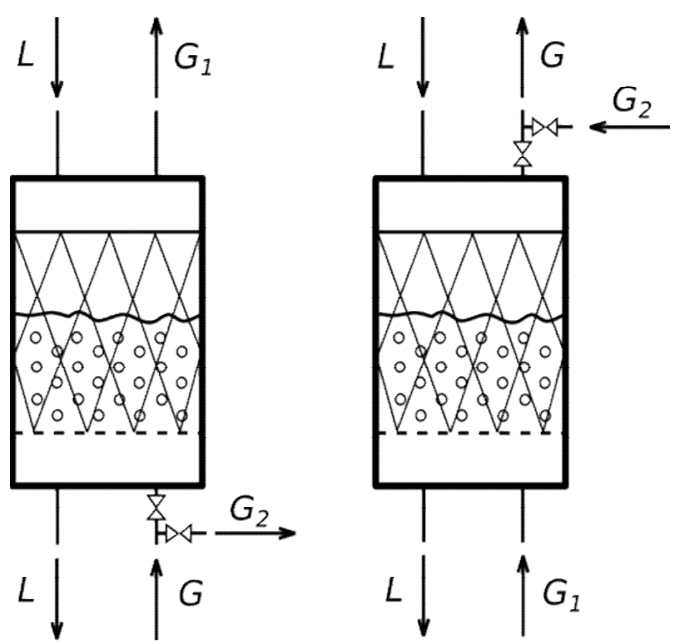

Fig. 1. The scheme of irrigated packed bed with pumping (at the left) and suction (at the right) of air. 


\subsection{Economic and investment aspect}

We conducted a preliminary economic assessment of constructing a bromine extraction unit. For calculations we used mine water processing volume of $500 \mathrm{~m}^{3} / \mathrm{h}$ with a mass concentration of bromide equal to $120 \mathrm{mg} / \mathrm{l}$; the annual production capacity is 400 tons. The initial data and resulting performance of the proposed pilot project are given in Table 3 .

Table 3. Pilot project performance indicators.

\begin{tabular}{|c|c|}
\hline Indicators & $\begin{array}{c}\text { Value of the } \\
\text { indicator }\end{array}$ \\
\hline \multicolumn{2}{|l|}{ Initial data } \\
\hline Production capacity, tons per year & 400 \\
\hline Annual sales, $\$ \mathrm{mln}$ & 0.98 \\
\hline $\begin{array}{l}\text { Initial investment (excluding infrastructure } \\
\text { costs), \$ mln }\end{array}$ & 0.72 \\
\hline Construction period, months & 30 \\
\hline Production cost, $\$$ ths/ton & 1.08 \\
\hline Risk-adjusted discount rate, $\%$ & 15 \\
\hline Investment horizon, years & 5 \\
\hline \multicolumn{2}{|c|}{ Calculated performance indicators } \\
\hline Discounted payback period, months & 52 \\
\hline Net present value, $\$ \mathrm{mln}$ & 0.24 \\
\hline Internal rate of return, $\%$ & 28.6 \\
\hline Profitability index & 1.39 \\
\hline
\end{tabular}

The implementation of this project is justified by its technical and economic indicators, the possibility of import substitution and 55 new work places that it creates. This project will diversify the country's chemical production and strengthen its economic security.

A promising option for the utilization of brominecontaining mine water of Kryvbas is production of calcium bromide, which is the main component of drilling fluids.

The traditional technology of calcium bromide production is based on reaction between liquid bromine and calcium hydroxide in the presence of a reducing agent (urea, formic acid or ammonia).

When bromine is extracted by air-desorption, the production process can be simplified and cheapened by absorbing bromine with calcium hydroxide directly from bromine-air mixture. In this case, the steps needed to obtain liquid bromine are skipped, leading to significant cost reduction of the final product [21].

In case of successful implementation of the pilot bromine extraction project, it can be scaled in order to greatly increase the production of bromine and/or its compounds. Future development of this project is associated with organization of complex processing of mine water (that contains sodium chloride, magnesium, potassium and other valuable components [14]) with a goal to obtain several target products.

The important aspects of the project are its business model and sources of financing. The lack of practical solution to the problem of mine water utilization in Kryvbas throughout years proves that it cannot be solved only with principles of market self-organization and private entrepreneurial initiative. It may be necessary to use mechanisms of public-private partnership (PPP) or even a public-private-international partnership.

A water management industry typically has a number of factors that restrain the implementation of PPP mechanisms. As indicated in [22], these factors include: (1) high cost and unprofitability of the industry from environmental and economic standpoints, (2) low quality of source water and potentially high penalties for water pollution, (3) low profitability of the water supply sector due to underestimation of water resources.

In contrast to solutions suffering from the listed restraining factors, we suggest a project that can take full advantage of the PPP mechanisms. Our project has a socio-environmental importance, commercial effectiveness and an innovative component. Mixed financing of the project can be carried out with resources of the State Regional Development Fund, environmental funds, international technical assistance, own funds of mining enterprises, and other investors. Depending on the sources of investment, various business models can be considered to implement the project. Examples of such models are given in [23].

\section{Implementing the sustainability project within a regional strategy framework}

The success of any project is largely determined by the institutional framework for its implementation. Currently, significant opportunities for implementing sustainability projects with innovative components are opening up within a regional development framework.

A distinctive feature of current regional development strategies is the use of smart specialization approach. In [24], we proved that the Dnipropetrovsk region has prerequisites to form smart specialization domains based on the development of chemical production.

In line with this idea, we propose a pilot project to create an innovative import-substituting production of bromine and/or its compounds from mine water of Kryvbas as a regional development project. Table 4 shows that our project proposal meets the key criteria for prioritizing regional development projects.

The project proposal meets the objectives of Strategy for Development of the Dnipropetrovsk region until 2027: A.1.1. "Development of high-tech and innovative industries"; B.2.2. "Improving the industrial waste management system" and the smart-objective "Developing potential of the chemical complex".

In the context of this study, it is important that connecting smart and sustainable growth through smart specialization approach is possible [25]. The project proposal has a positive impact on the main dimensions of sustainable development, including social, economic, environmental and innovative dimensions, see Table 5.

The regional report "Sustainable Development Goals: Dnipro-2030" [26] specifies the region's conditions and objectives within the national Sustainable Development Goals (SDGs).

According to the expert recommendations on determining priority measures to achieve the SDGs of 
the Dnipropetrovsk region, the achievement of SDG-9 "Industry, innovation and infrastructure" will be facilitated by "development of enterprises based on the newest industrial waste processing technologies and obtaining cheap raw materials for the chemical and construction industries" [26, p. 150]. Our proposed project meets these recommendations and contributes to implementation of other regional goals:

Table 4. Conformity of the project proposal with key criteria for prioritizing regional development projects.

\begin{tabular}{|c|c|}
\hline Criteria & Compliance with criteria \\
\hline $\begin{array}{c}\text { Alignment with the } \\
\text { regional Strategy }\end{array}$ & $\begin{array}{c}\text { The project has an obvious contribution } \\
\text { to more than one strategic goal } \\
\text { (program) }\end{array}$ \\
\hline Impact of the project & $\begin{array}{c}\text { The project has an impact on the entire } \\
\text { region (if scaled) }\end{array}$ \\
\hline Project focus & $\begin{array}{c}\text { Business project with societal and } \\
\text { environmental components }\end{array}$ \\
\hline $\begin{array}{c}\text { Administrative } \\
\text { feasibility }\end{array}$ & $\begin{array}{c}\text { The project provides for a partial } \\
\text { involvement of regional authorities }\end{array}$ \\
\hline \multicolumn{2}{|c|}{ Readiness for implementation } \\
\hline Project status & $\begin{array}{c}\text { There are the idea and preliminary } \\
\text { calculation of the project }\end{array}$ \\
\hline Funding & $\begin{array}{c}\text { Cost structure and funding source are } \\
\text { partially substantiated }\end{array}$ \\
\hline $\begin{array}{c}\text { Non-financial } \\
\text { resources }\end{array}$ & $\begin{array}{c}\text { There are scientific and technological } \\
\text { developments, hydro-mineral resources, } \\
\text { qualified project executors }\end{array}$ \\
\hline
\end{tabular}

Table 5. Impact of the project proposal on the dimensions of sustainable development.

\begin{tabular}{|c|c|}
\hline Dimensions & Impact \\
\hline Social & $\begin{array}{c}\text { Creation of new jobs. Formation of new social } \\
\text { needs and new market segments in the future }\end{array}$ \\
\hline Economic & $\begin{array}{c}\text { Increase in gross regional product. Production } \\
\text { diversification. Attraction of investments. } \\
\text { Growth of tax revenues due to a rising in the } \\
\text { tax base. Reduction imports. Expansion the } \\
\text { export potential of the chemical sector. } \\
\text { Reduction budget costs for environmental } \\
\text { activities through the production and sale of } \\
\text { marketable products }\end{array}$ \\
\hline Environmental & $\begin{array}{c}\text { Reduction the negative impact of industrial } \\
\text { waste by improving of waste management and } \\
\text { the targeted use of local hydro-mineral } \\
\text { resources }\end{array}$ \\
\hline Innovative & $\begin{array}{c}\text { Use of original innovative technical solutions } \\
\text { that significantly reduce capital costs, increase } \\
\text { the process efficiency and ensure the project's } \\
\text { profitability }\end{array}$ \\
\hline
\end{tabular}

SDG-8 "Decent work and economic growth": 8.1 Ensure sustainable growth of GDP / GRP through modernization of production, development of innovations, increase of export potential, promote products with a high share of added value in foreign markets;

SDG-9 "Industry, innovation and infrastructure": 9.3.1. Increase sales of innovative products; 9.4. Stimulate the creation of technological innovations and innovative equipment of enterprises; 9.5. Ensure the provision of state financial assistance to enterprises with technological innovations to stimulate innovative activity;

SDG-12 "Responsible consumption and production": 12.4. Reduce the volume of waste generation and increase the volume of their recycling based on innovative technologies and production; 12.8. Taking advantage of the circular economy and closed supply chains;

SDG-17 "Partnerships for the goals": 17.1. Mobilize additional financial resources through the promotion of investment by foreign and domestic investors; 17.2. Develop partnerships between government and business to achieve the Sustainable Development Goals.

\section{Conclusions}

Sustainable development of the Dnipropetrovsk region is impossible without solving a critical environmental, social and economic problem of utilization of highly mineralized mine water in the Kryvyi Rih Basin.

In this work, we proposed and justified a pilot project that produces bromine and/or its compounds from mine water of Kryvbas. The project is based on the application of authors' innovative technical and technological solutions. Other advantages of the project include use of hydro-mineral and other local resources, improved waste management, environmental focus, import substitution and development of the region's export potential.

Implementation of the project will contribute to the achievement of sustainable development goals of the Dnipropetrovsk region, notably SDG-8, 9, 12 and 17.

\section{References}

1. N. Derlukiewicz, Development of smart and sustainable economy in the European Union. European Journal of Sustainable Development 3(4), 151-162 (2014). doi:10.14207/ejsd.2014.v3n4p151

2. I. Ilic-Krstic, A. Ilic, D. Avramovic, The three dimensions of sustainable development: environment, economy and society. In Proseedings of the 18th Conference of the series Man and Working Environment, ed. by D. Cvetkovitc, I. Krstic (University of Nis, Nis, 2018), pp. 197-202

3. A.M. Teodorescu, Sustainable development, a multidimensional concept. Annals - Economy Series, Special - Information society and sustainable development, 82-86 (2015)

4. S. Talukdar, Pursuing sustainability: a case for regional approach. Community Change 2(1) (2018). doi:10.21061/cc.v2i1.a.14

5. D. Hanss, G. Bohm. Sustainability seen from the perspective of consumers. International Journal of Consumer Studies 36(6), 678-687 (2012) doi:10.1111/j.1470-6431.2011.01045.x

6. E. Holden, K. Linnerud, D. Banister, Sustainable development: our common future revisited. Global Environmental Change 26, 130-139 (2014) doi:10.1016/j.gloenvcha.2014.04.006 
7. K. Birch, D. MacKinnon, A. Cumbers, Old industrial regions in Europe: a comparative assessment of economic performance. Regional Studies 44, 35-53 (2010).

doi:10.1080/00343400802195147

8. L. Coenen, J. Moodysson, H. Martin, Path renewal in old industrial regions: possibilities and limitations for regional innovation policy. Regional Studies 49, 850-865. (2015)

doi:10.1080/00343404.2014.979321

9. V. Vishnevsky, I. Aleksandrov, A. Polovyan, Scenarios of the old industrial regions' development: selecting the methodology. Environment, Development and Sustainability 13, 65-78 (2011). doi:10.1007/s10668-010-9248-6

10. O. Amosha, O. Lyakh, M. Soldak, D. Cherevatskyi, Institutional determinants of implementation of the smart specialisation concept: case for old industrial coal-mining regions in Ukraine. Journal of European Economy 17(3), 305-332 (2018)

11. O. Snihova, Mozhlyvosti formuvannia postindustrialnykh konkurentnykh perevah staropromyslovykh rehioniv Ukrainy (The possibilities of post-industrial competitive advantages' formation of old-industrial regions of Ukraine). Economic Herald of the Donbas 1, 39-51 (2017)

12. Yu.G. Vilkul, N.I. Stupnik, D.V. Brovko, P.S. Kirichenko. Puti snizheniya tekhnogennogo vliyaniya shakhtnykh i kar'ernykh vod na presnovodnye ob"ekty Krivbassa (Ways to reduce the anthropogenic impact of mine and quarry waters on freshwater bodies in Kryvbas) In Forum hirnykiv - 2016, vol. 2 (2016), pp. 138-144

13. Dnipropetrovska oblasna rada, Stratehiia rozvytku Dnipropetrovskoi oblasti na period do 2020 roku (Strategy for Development of the Dnipropetrovsk Region until 2020). (2014)

14. P.I. Pigulevskiy et al., Perspektivy ispol'zovaniya zhidkikh otkhodov $\mathrm{v}$ kachestve istochnika mineral'nykh soedineniy (na primere Krivorozhskogo zhelezorudnogo basseyna) (Prospects of use of liquid wastes as a source of mineral compounds (on an example of Krivoy Rog iron ore basin)). Dig. Geliogeofizicheskie issledovaniya (2015),

http://vestnik.geospace.ru/php/download.php?id=UP LF87d35d41e3d163230c9342ca43b5be49.pdf.

Accessed 17 Dec 2019

15. M. Garside, Major countries in worldwide bromine production from 2014 to 2018 (Statista, 2019), http://www.statista.com/statistics/264926/worldbromine-production/. Accessed 23 Dec 2019

16. Y. Zhang et al., Development status and future development trend of bromine. IOP Conf. Ser.: Earth Environ. Sci. 300, 032018 (2019). doi:10.1088/1755-1315/300/3/032018

17. Y. Hirayama, Global bromine industry and its outlook (ICL-IP Japan, 2008), http://www.bromine.chem.yamaguchi-

u.ac.jp/library/L02_Global\%20

Bromine\%20Industry.pdf. Accessed 23 Dec 2019

18. C.J. Nalepa, 25 years of bromine chemistry in industrial water systems: a review (NACE International 04087, 2004),

http://envirotech.com/wpcontent/uploads/2016/01/NACE-Bromine-

Chemistry-Review-1.pdf. Accessed 23 Dec 2019

19. B. Winid, Bromine and water quality - Selected aspects and future perspectives. Applied Geochemistry 63, 413-435 (2015). doi:10.1016/j.apgeochem.2015.10.004

20. V.I. Ksenzenko, D.S. Stasinevich, Khimiya $i$ tekhnologiya broma, yoda $i$ ikh soedineniy (Chemistry and technology of bromine, iodine, and their compounds). (Khimiya, Moscow, 1995)

21. R.A. Sarkarov, A.I. Ovchinnikov, Poluchenie bromida kal'tsiya i tyazhelykh burovykh zhidkostey iz podzemnykh vod (Preparation of calcium bromide and heavy drilling fluid from groundwater). In Sostoyanie $i$ perspektivy razvitiya proizvodstva yoda, broma i ikh proizvodnykh, soedineniy magniya i margantsa, a takzhe antipirenov $v$ Ukraine, Rossii $i$ stranakh SNG (NIITEKhIM, Cherkassy, 2003), pp. 75-76.

22. I. Bystryakov, D. Klynovyi, Problematyka implementatsii yevropeiskykh publichnopryvatnykh formativ staloho hospodariuvannia $\mathrm{v}$ Ukraini (Problems of implementation of european public-private forms of sustainable entrepreneurship in Ukraine). Environmental Economics and Sustainable Development 5, 14-20 (2019)

23. I. Kocheshkova, Mozhlyvi formy pidpryiemstv $z$ pererobky promyslovykh vidkhodiv i dzherela finansuvannia yikh stvorennia ta funktsionuvannia (Feasible forms of enterprises for industrial waste processing, and financial sources for their establishment and functioning). Economic Herald of the Donbas 3, 63-69 (2019) doi:10.12958/18173772-2019-3(57)-63-69

24. O.I. Amosha, H.Z. Shevtsova, N.V. Shvets, Peredumovy smart-spetsializatsii DonetskoPrydniprovskoho makrorehionu na osnovi rozvytku khimichnoho vyrobnytstva (Prerequisites for smart specialization of Donetsk-Prydniprovsky macroregion based on chemical production development). Economy of Industry 3, 5-33 (2019). doi:10.15407/econindustry2019.03.005

25. A. Doranova, E. Griniece, M. Miedzinski, A. Reid, Connecting smart and sustainable growth through smart specialisation. A practical guide for ERDF managing authorities (Publications Office of the European Union, Luxembourg, 2012)

26. V.H. Panchenko, N.V. Reznikova, Tsili staloho rozvytku: Dnipro-2030. Rehionalna dopovid (Sustainable Development Goals: Dnipro-2030. Regional report). (UNDP, 2018) 